\title{
Mengapa PBL (Masih) Diperdebatkan di Fakultas Kedokteran?
}

\section{Elisabeth Rukmini}

Fakultas Kedokteran Universitas Katolik Indonesia Atma Jaya, Jakarta

\begin{abstract}
Problem-based learning (PBL) has been implemented widely in most of faculty of medicine in Indonesia. Nevertheless, PBL as a learning method is still debated. This article tried to unravel the debate of PBL implementation in medical schools, as well as recommending important notes in order to find a well-defined PBL and to improve its implementation. PBL should be acknowledged as one of the student centered learning methods. Therefore, this condition would not rule out the possibility of the empirical progress in PBL implementation in faculty of medicine in Indonesia.
\end{abstract}

Keywords: problem-based learning, student centered learning

\section{Abstrak}

Problem-based learning (PBL) sudah dilaksanakan di hampir seluruh fakultas kedokteran Indonesia. Meskipun demikian, PBL sebagai metode pembelajaran masih terus diperdebatkan. Tulisan ini mencoba mengurai perdebatan PBL dalam penerapannya di fakultas kedokteran, sekaligus merekomendasikan beberapa catatan penting agar PBL terus dapat dimaknai dan berkembang. PBL perlu dipandang sebagai salah satu metode student centered learning sehingga tidak menutup kemungkinan perkembangannya dalam implementasi yang empirik di fakultas kedokteran di Indonesia.

Kata Kunci: problem-based learning, student centered learning

\section{PENDAHULUAN}

"Teaching and learning are not synonymous; we can teach, and teach well, without having the students learn" (George

Bodner). ${ }^{1}$

Kutipan di atas rasanya layak untuk direnungkan dalamdalam oleh kalangan pendidik (kedokteran) dalam mengevaluasi diri sendiri terhadap proses belajar mengajar di fakultas kedokteran di Indonesia. Banyak pandangan berdasarkan bukti nyata di dunia pendidikan bahwa pembelajaran pasif seperti perkuliahan dan ceramah yang bersifat satu arah tidak efektif bagi mahasiswa. Mengapa kita masih enggan untuk membuka paradigma lain dalam proses belajar mengajar. Mengajar dan belajar adalah dua hal yang berbeda. Perkembangan teori pembelajaran yang berbasis pada penelitian telah membuktikan arah proses belajar yang lebih efektif.
Untuk itu kita perlu melihat konsep perkembangan dasar dan teori tentang pembelajaran.

\section{TEORI PEMBELAJARAN}

Teori pembelajaran berkembang dari waktu ke waktu, sejak Plato (490s B.C.E.). Jika Plato percaya bahwa ilmu pengetahuan ada dalam diri masing-masing orang, John Locke (sekitar 1690) mempercayai ilmu pengetahuan telah ada sejak bayi tetapi perlu diaktifkan. Aktivasi yang dimaksud oleh Locke adalah pengalaman sensing. Locke jugalah yang kerap kali dianggap sebagai pengusung ide atomisasi bahan ajar, teorinya dinamakan Lockean Atomist model. Dari Plato ke Locke perubahan pemahaman proses belajar bersifat perubahan cara pandang terhadap pembelajar. Plato menganggap pembelajar adalah penonton sedangkan Locke

Korespondensi: Pluit Raya \#2 Jakarta 14440 Telp. 021-6693168 ext. 235 Fax: 021-6606123

Email: elisabeth.rukmini@atmajaya.ac.id 
menganggap pembelajar adalah lemari kosong yang siap diisi dengan cukilan-cukilan (atomisasi) pengetahuan. $^{2}$

Perkembangan teori atomisasi dari Locke mengantarkan pada behaviorism terutama karena berkembangnya eksperimentasi ilmu di awal abad ke-20. Kaum behaviorist percaya pada pengukuran atau eksperimentasi. Tingkah laku dengan demikian bisa diukur dengan eksperimentasi terhadap binatang, misalnya percobaan Pavlov. Respon anjing diperoleh karena stimulus dari Pavlov. Dengan demikian, fokus utama behaviorism adalah proses belajar siswa dapat ditunjukkan jika ada respon terhadap stimulus yang diberikan oleh guru. ${ }^{2}$ Artinya, menurut kaum behaviorist, semakin banyak stimulus (misalnya: latihan, ujian, pekerjaan rumah) yang diberikan oleh guru kepada muridnya, maka akan semakin banyak hal yang dikuasai muridnya.

Persoalan kemudian muncul ketika kita sebagai guru sering melihat betapa sudah banyaknya latihan, catatan, pekerjaan rumah dan ujian yang kita berikan kepada murid-murid kita; tetapi murid masih tidak belajar banyak, masih saja ada nilai merah, masih saja ketika lulus terlupa bahan-bahan ajarnya. Behaviorism dalam hal ini gagal menerangkan fenomena ini.

Gestalt teori muncul pada awal abad kesembilanbelas yang mengutamakan struktur belajar dan independensi untuk pembelajaran bermakna (meaningful learning). John Dewey (1859-1952) mengawali dengan ide pendekatan problem solving dalam proses belajar. Era ini juga menjadi penanda matinya behaviorisme dengan ide belajar pasifnya.

Tidak lengkap jika tidak menyebutkan Piaget (18961980) yang mengawali teori perkembangan kognitif sebagai landasan belajar. Piaget, seorang ahli biologi yang terbiasa dengan observasi, membedakan observasi yang dilakukannya dengan eksperimentasi Pavlov pada era behaviorisme. Piaget mengamati perkembangan kognitif manusia dari bayi hingga dewasa, mula-mula dengan melihat perkembangan anaknya sejak hari pertama dilahirkan. Piaget dengan teori perkembangan kognitifnya menjadi awal era konstruktivisme.

Perspektif terpenting dari teori perkembangan kognitif oleh Piaget yang sangat berpengaruh pada pendidikan adalah manusia akan belajar bila ia berlaku sebagai partisipan aktif dan bukan pasif. ${ }^{3}$ Vygotsky kemudian memperkaya konsep aktif ini dengan menambahkan interaksi antara pembelajar muda dengan orang yang lebih dewasa atau kaya dalam pengetahuan. Hal yang jelas sama antara Piaget dan Vygotsky adalah paham bahwa pembelajar secara aktif mengkonstruksi pengetahuannya. ${ }^{4}$ Konstruktivisme dengan demikian merespon kenyataan bahwa betapa banyak stimulus (tugas, catatan, ujian) yang diberikan guru tidak dapat memaksa siswanya benar-benar belajar secara efektif dan mendayagunakan ilmu yang telah dipelajarinya. Fakta ini jelas menggiring pada kenyataan bahwa knowledge dikonstruk oleh pembelajar. ${ }^{1,5}$

Implikasi konstruktivisme ini menunjukkan metode pembelajaran yang berpusat pada pembelajar akan membantu proses belajar secara maksimal. Keterpusatan ini juga berkaitan dengan interaksi antara pembelajar dengan lingkungan sosial. Konstruksi pembelajar juga menekankan pada proses belajar lebih daripada produk belajar. Hal ini berdampak pada fasilitasi atau penghargaan terhadap proses belajar yang berbeda-beda. ${ }^{2}$

\section{STUDENT CENTERED LEARNING (SCL)}

Jika kita konsisten dengan penghargaan terhadap proses belajar siswa, maka tampak jelaslah perbedaan knowledge acquisition antara konstruktivisme dan teori tradisional. "Knowledge should no longer be judged in terms of whether it is true or false, but in terms of whether it works". ${ }^{5}$ Dua faktor utama tersebut, variasi proses belajar siswa dan knowledge acquisition, menjadikan peran guru pada paradigma konstruktivisme bergeser. Guru bukanlah sumber ilmu yang utama, bukanlah pusat belajar, bukanlah penentu kebenaran ilmu, bukanlah penentu proses belajar. Peran guru bergeser menjadi fasilitator yang mengerti dan berupaya membukakan jalan bagi proses belajar siswa yang beragam. Peran guru bergeser menjadi motivator aktif yang membuka kemungkinan-kemungkinan knowledge acquisition dari sumber-sumber yang variatif. Jika digabungkan keduanya, guru bergeser menjadi negosiator dalam proses belajar mengajar, "from teaching by imposition to teaching by negotiation".

Negosiasi proses belajar hanya bisa terlaksana bila metode bergeser menjadi fokus pada siswa, student centered learning (SCL). Metode SCL sangat bervariasi. SCL dapat diklasifikasikan berdasarkan proses belajarnya dari "terarah" oleh guru atau fasilitator ke "open inquiry" yang sangat terbuka pengembangannya tergantung proses belajar siswa; di antara dua kutub tersebut tersebar variasi yang beragam. ${ }^{6}$ Contoh metode SCL yang masih 
diarahkan atau meletakkan guru sebagai fasilitator utama adalah diskusi terarah, kuliah plus diskusi terarah dan jigsaw. Pada rentang dua kutub itu terdapat beberapa contoh: metode guided inquiry, peer assisted learning (PAL), peerled team learning (PLTL), problem based learning, casebased learning, fishbowling. Sementara pada kutub open inquiry terdapat misalnya discovery learning dan project-based learning. Ragam metode SCL ini menunjukkan luasnya pilihan guru untuk memfasilitasi atau bernegosiasi dalam proses belajar. Ragam ini juga menunjukkan bahwa PBL hanyalah salah satu dari metode SCL.

\section{PBL HANYALAH SALAH SATU PENDEKATAN PEMBELAJARAN BERBASIS SISWA}

Ketika McMaster University mendirikan Faculty of Health and Science di Canada mendirikan jurusan baru ini, dunia pendidikan kedokteran tercengang dengan pendekatan PBL. Universitas ini meluluskan lulusan pertamanya di tahun 1972. Sejak itu, dalam era tahun 1970an hingga 1980an bermunculan sekolah-sekolah kedokteran yang ikut menerapkan PBL misalnya Michigan State University, University of Hawaii, Harvard University, ketiganya di Amerika Serikat, University of Sherbroke di Canada, Maastricht University di Belanda dan The New Castle University di Australia.? Tampak jelas PBL bukanlah barang baru di dunia pendidikan kedokteran. Meskipun demikian, PBL mulai dikenal dan diterapkan secara luas di Indonesia baru sekitar tahun 2008 melalui program-program pelatihan pendidikan kedokteran.

PBL digunakan di Fakultas Kedokteran karena sifatnya yang mengedepankan collaborative learning dan integratif. Meskipun demikian, perlu dicatat bahwa kedua sifat tersebut juga dapat ditemukan dalam metode SCL yang lain. Sifat collaborative learning dapat ditemukan dalam diskusi kelompok, PAL, PLTL, case-based learning dan jigsaw. Sifat integratif juga dapat ditemukan dalam diskusi kelompok, project-based learning, case-based learning dan bed side teaching. Jelaslah bahwa persoalan mengintegrasikan bahan tidak selalu harus dengan PBL saja. PBL adalah salah satu pendekatan SCL.

Pertanyaannya bagaimana learning methodyang lain dapat menjamin integrasi bahan? Project based learning, misalnya, dalam metode ini siswa diberi tugas membuat suatu proyek. Tugas ini dapat terarah dan diarahkan oleh negosiator (baca: guru). Seorang negosiator pendidikan dapat memberikan proyek misalnya memulai pusat kesehatan di desa $\mathrm{X}$ atau proyek sunatan massal.

Dapatkah sifat integratif juga ada dalam perkuliahan? Apakah ada narasumbernya? Apakah ada satu orang yang cukup mampu mengintegrasikan bidang-bidang terkait untuk pemahaman sistem tertentu? Jawabannya pasti ada. Tetapi orang yang seperti ini tidaklah banyak. Kembali lagi ke akar sejarah pendidikan di Fakultas Kedokteran, atomisasi bahan (ingat Lockean Theory) dilakukan dalam departemen-departemen. Jadi, produk pengajar saat ini tentu secara natural bukanlah staf akademik yang dengan mudah dapat memberikan bahan terintegrasi. Kotak atomisasi (baca: departemendepartemen keilmuan) telah sedikit banyak berpengaruh pada spesialisasi bahan yang dengan demikian mempersulit kita untuk berpikir integratif. Jadi, tidaklah heran jika perkuliahan yang integratif, hidup, dan menarik untuk diperbincangkan di dalam maupun di luar kelas menjadi barang amat langka. Jika demikian, perlu kiranya dipikirkan apakah metode perkuliahan yang integratif sungguh dapat dilakukan?

\section{STUDI TENTANG PBL}

Hays ${ }^{8}$ dalam editorial Medical Journal of Australia memberi poin-poin penting yang dituntut dalam pendidikan kedokteran. Penulis ini mencantumkan mengapa perkembangan pendidik(an) kedokteran perlu diperhatikan dan diakui strateginya, misalnya perlunya riset pendidikan kedokteran terus dilaksanakan berdasarkan perubahan tuntutan pendidikan kedokteran. Penelitian pendidikan kedokteran perlu dihargai setara dengan penelitian keilmuan lainnya dalam bidang kedokteran dan kesehatan. Terkait dengan hal ini, studi mengenai PBL di Indonesia dengan demikian perlu didalami berdasarkan data lapangan di berbagai FK di Indonesia yang harus diakui cukup heterogen kondisinya. Kesempatan untuk hal ini perlu dibuka lebar demi penyesuaian PBL (dan metode belajar lainnya) bagi FK kita yang beragam.

Berkaitan dengan hasil studi mengenai PBL, kita dapat melihat review article yang sangat komprehensif pertama kali baru ada tahun1993,9,10 Padahal, PBL sudah dimulai sejak tahun 1970-an. Vernon ${ }^{9}$ dan Albanese ${ }^{10}$ mengambil data jurnal-jurnal yang terbit di Eropa dan Amerika 
Serikat pada tahun 1970-an hingga awal 1990-an. Jika hal ini dibandingkan dengan kondisi di Indonesia, maka umur penerapan PBL di FK se-Indonesia jelaslah masih muda sekitar 10 tahun. Sementara itu bila ditilik jumlah publikasi terkait PBL yang diselenggarakan di bidang kedokteran dari tahun 1974-1980 dalam jurnal-jurnal Eropa dan Amerika sekitar 1600 artikel. Di Indonesia, hingga saat ini belum ada sistem deteksi yang memadai secara real time untuk melacak berapa banyak publikasi serupa mengenai PBL berbasis data empirik. Diseminasi di tingkat nasional dalam pertemuan rutin terkait medical education tentu tak pernah lepas dari laporan penelitian PBL. Jika kita mengambil angka kasar saja, kira-kira ada sedikitnya satu kali pertemuan ilmiah terkait medical education setiap tahunnya yang berskala nasional. Jika dalam pertemuan ini didiseminasikan 20 hasil penelitian terkait PBL, maka pada tahun keenam ini, baru ada 120 hasil penelitian terkait PBL, inipun tidak semuanya dipublikasikan dalam bentuk artikel. Angka ini tentu hanya angka kasar, meskipun demikian dapat dilihat bila dibandingkan dengan jumlah hasil pencarian publikasi di atas, angka kasar ini jelas sangat rendah. Ini membuktikan, staf akademik FK di Indonesia belum cukup melirik pentingnya bukti empirik PBL secara lokal. Hal ini juga membuktikan kebijakan pendidikan kedokteran di Indonesia jelas perlu meluangkan tenaga, waktu, dana dan apresiasi terhadap penelitian pendidikan kedokteran.

Albanese ${ }^{10}$ melakukan studi meta analysis untuk melihat PBL dalam keterkaitan antara outcomes dan implementation. Studi meta analysis ini dilakukan dengan menilik publikasi dalam rentang waktu tahun 1972-1992. Menurut Albanese ${ }^{10}$ mahasiswa dan staf akademik menikmati metode PBL sebagai salah satu pendekatan pembelajaran. Bagaimana dengan para staf akademik di FK Indonesia, apakah staf menikmati cara belajar dengan PBL? Pada mahasiswa ditemukan minat yang cukup terhadap PBL. ${ }^{11-13}$ Mahasiswa di FK UAJ menyadari pentingnya PBL dan hal-hal apa yang mereka pelajari melalui PBL. Meskipun demikian dalam presentasi yang sama, Rukmini ${ }^{13}$ juga mencatatkan kritik mahasiswa terhadap tutor PBL yang tidak menunjukkan minat sama sekali untuk menjadi tutor PBL.

Tulisan Albanese ${ }^{10}$ lebih dari satu dasawarsa lalu, demikian juga meta analysis ini, Vernon dan Blake juga menemukan kurangnya penguasaan basic medical science pada mahasiswa PBL. Albanese ${ }^{10}$ menunjukkan bukti- bukti dari 25 tahun penerapan PBL di Eropa dan Amerika yang merujuk pada kurangnya kemampuan kognitif mahasiswa PBL dibandingkan dengan mahasiswa yang menempuh jalur konvensional, meskipun demikian klaim ini dinyatakan tidak selalu signifikan dan tidak berulang. Sebagai keunggulan PBL, Albanese ${ }^{10}$ menyatakan bahwa kemampuan menyelesaikan masalah pada mahasiswa PBL ditemukan lebih baik dan signifikan dibandingkan mahasiswa tradisional. Temuan ini setali dengan dua studi meta analisis yang lain.,14 Dalam rentang yang sama dan setelah tahun 1990-an terdapat penyesuaian implementasi PBL di berbagai universitas sebagai upaya mengatasi kurangnya penguasaan kognitif. ${ }^{15-19}$

Evaluasi PBL merupakan bukti studi terhadap PBL. Newman ${ }^{20}$ menyebutkan perlunya evaluasi PBL dilakukan dengan mencantumkan descriptive causation. Sejalan dengan hal ini, evaluasi PBL di FKUAJ juga menguraikan berbagai macam faktor yang dipandang oleh mahasiswa sebagai faktor sukses PBL, oleh karenanya perlu evaluasi yang terfokus jika benar-benar ingin memperbaiki aspek tertentu dari PBL. ${ }^{13}$

\section{REKOMENDASI UNTUK PBL}

Desain pembelajaran selalu mengambil peranan penting. Demikian pula dengan desain PBL dari skenario, tutor, alokasi waktu, sumber belajar dan detil tindakan yang harus dilakukan pada saat implementasi. Hung ${ }^{17}$ mengembangkan konsep 3C3R: Context, Content, Connection, and Researching, Reflecting, Reasoninguntuk desain PBL. Jelaslah tampak bahwa tugas desain PBL ini adalah tambahan kerja ekstra bila dibandingkan dengan sekedar kuliah atau kegiatan teacher centered.

Pembuatan skenario yang tidak saja bersifat klinis tetapi problem luas dan melibatkan basic sciences perlu dipikirkan, sehingga mahasiswa tidak tertuju pada kasus (case-based learning) tetapi pada reasoning. Dalam berbagai pertemuan evaluasi PBL secara internal hampir selalu ada keluhan bahwa learning objectives tidak tercapai. Hal ini kontras dengan penelitian yang membandingkan goal-free problem versus goal-defined problem. Verkoeijen mengungkapkan bahwa PBL dengan goal-free problem lebih mendorong mahasiswa untuk memperluas cara pandang dan belajarnya, mahasiswa meluangkan waktu belajar yang lebih banyak dibandingkan dengan kelompok goal-defined problem. $^{21}$ 
Bahan ajar yang variatif perlu menjadi prasyarat untuk menjalankan PBL. Te Winkel ${ }^{22}$ menunjukkan bahwa mahasiswa meluangkan lebih banyak waktu ketika disediakan sumber utama yang lebih variatif. Jelaslah, tuntutan dalam PBL berarti menyediakan dan menyebutkan sumber-sumber utama yang variatif kepada mahasiswa.

Bila dalam metode tradisional, guru menempati posisi pusat, dalam PBL peranannya yang bergeser menjadi tutor tidak kalah krusialnya. Maudsley ${ }^{23}$ menuturkan hasil studinya terhadap refleksi tutor PBL setelah pelatihan tingkat dasar, tampak tutor PBL sulit menghindari bertindak lebih sebagai guru dibandingkan sebagai fasilitator di ruang PBL dan merasa perlu penegasan kapan dan bagaimana mengintervensi kelompok diskusi.

Pelatihan tutor yang dijalankan perlu mendorong terbentuknya paradigma yang sama. Tutor yang aktif adalah tujuan pelatihan tutor. Kurangnya penguasaan kognitif mahasiswa sangat mungkin dikarenakan tutor yang belum memahami filosofi PBL. Shields et $\mathrm{al}^{24}$ menuliskan tentang pelatihan tutor yang sifatnya melatih tutor sebagai pemimpin diskusi, tidak sekedar fasilitator.

Review article dari Dochy et al. ${ }^{14}$ dan Gijbels et al..$^{25}$ yang melakukan studi meta analisis berkaitan dengan asesmen PBL merangkumkan variasi penilaian yang ditemukan secara empirik dan merupakan inovasi lanjutan PBL. Selain National Board of Medical Examiners: United States Medical Licensing Examination (USMLE), penulis juga menemukan beberapa metode lain: Modified Essay Questions (MEQ), Progress Test, Free Recall, Standardized Patient Simulations, Essay Questions, Short-Answer Questions, Multiple-Choice Questions, Oral Examination, Performance-Based Testing: Rating Case-Based Examinations. Bila ditilik dari variasi metode penilaian tampaklah rentang metode yang beragam. Seluruh metode yang disebutkan di atas dianggap dapat menilai knowledge acquisition. Program pendidikan dokter kita perlu semakin berinovasi dalam bentuk-bentuk assessment yang sesuai dengan filosofi PBL, selain terus memperbaiki tiga buah assessment berikut: peer-assessment, self-assessment dan tutor assessment yang dapat menilai sikap dan keterampilan.

Seperti telah disebutkan di awal tulisan ini, barangkali problem utama perdebatan mengenai PBL ini terletak pada paradigma dosen sebagai SDM utama pendidikan kedokteran yang berbeda dengan filosofi PBL. PBL cukup bertentangan dengan otonomi dosen, dalam arti dosen tidak mempunyai kekuasaan mandiri. Dalam PBL, dosen dituntut selalu dan harus bisa bekerja sama. Paradigma independensi keilmuan yang dimilliki oleh dosen selama puluhan tahun (akibat atomisasi bahan) termasuk selama itulah mentor kita memperlakukan kita, kini perlu ditinjau ulang. Pada kalangan kedokteran yang profesinya sangat independen, kita perlu secara lapang dada menerima bahwa tidak ada kekuasaan mutlak pada perorangan dosen dalam metode PBL dan independensi perlu dinegosiasikan dengan kerja tim. Persoalannya, tidak ada saat tunda lagi untuk memulai negosiasi ini, harus dilakukan.

Ketaatan terhadap proses tentu akan mendorong inovasi atau perbaikan bagi PBL di Program Pendidikan Dokter Indonesia. Taat proses akan tampak bila desain PBL terus berkembang sesuai masukan berbagai pihak. Artinya, peletak landasan perubahan adalah evaluasi dan bukan kasus anekdotal. Evaluasi yang berbasis pada masukan stakeholder perlu dimaknai sungguh-sungguh. Stakeholder di sini menyangkut penyelenggara pendidikan, koordinator PBL, tutor dan mahasiswa. FKUAJ selama ini melakukan evaluasi dengan cara deskriptif. ${ }^{12,13}$ Hasil evaluasi menunjukkan kecenderungan kebosanan mahasiswa terhadap PBL sejak semester kedua. Beberapa blok secara mandiri juga mengadakan evaluasi terhadap PBL dari sisi mahasiswa dan tutor. Masukan tutor menunjukkan perlunya penguatan dalam cara berpikir dan analisis mahasiswa. Pendekatan evaluasi deskriptif saja barangkali tidak cukup, perlu ada evaluasi yang bersifat pengukuran. ${ }^{20}$ Meskipun demikian pendekatan deskriptif dapat memberi gambaran singkat dan cepat seperti yang dilakukan Usmani dengan mendeskripsikan tingkat kesetujuan mahasiswa, tutor yunior dan tutor senior terhadap PBL. ${ }^{26}$ Penelitian-penelitian kuantitatif dan kualitatif dapat mendorong berkembangnya PBL.

Bagaimana dengan karakter mahasiswa Indonesia, apakah mahasiswa kita menjadi permasalahan dalam PBL? Perlu kejelian mengevaluasi hal ini. Papinczak ${ }^{27}$ melalui penelitiannya menyimpulkan bahwa kelompok mahasiswa yang belajar dengan cara deep learning cenderung dapat mengatasi problem dalam PBL, tidak cepat bosan, tidak jenuh. Hasil serupa diperoleh dari studi Reid ${ }^{28}$ dengan tambahan bahwa tinggi rendah skor mahasiswa terhadap pengukuran cara belajar (deep atau surface learning) tidak berubah dari awal hingga akhir masa kuliah. Dapat dikatakan mahasiswa yang lebih 
mempersiapkan diri untuk meaningful learning akan menghargai upayanya dan jerih payah kelompoknya.

Latar belakang pendidikan menengah mahasiswa yang beragam dari Sabang sampai Merauke, demikian juga fasilitas fakultas kedokteran di penjuru Indonesia yang tidak selalu sama, memunculkan permasalahan lain. PBL tidak selalu menuntut fasilitas yang memadai seperti koneksi internet yang cepat dan ruang-ruang kecil tempat diskusi berlangsung. Kedua hal ini hanya sekunder dibanding-kan makna proses belajar dalam PBL. Jika tidak ada internet pun PBL masih bisa berlangsung. Bukankah komponen utamanya sudah ada? Mahasiswa FK menjadi komponen utama. Komponen kedua adalah tutor. Komponen ketiga adalah skenario yang mendorong kearah diskusi dan proses belajar yang baik. Latar belakang prior knowledge mahasiswa yang berbeda, telah dibuktikan oleh Vigotsky ${ }^{4}$ menjadi pendorong penguasaan materi dalam kelompok kecil.

\section{KESIMPULAN}

Penerapan PBL di FK perlu secara terus menerus evaluasi sehingga mendorong, revisi terus menerus menuju perubahan paradigma berpikir anggota sivitas akademikanya. Studi PBL telah berkembang luas tetapi secara empirik prodi kedokteran di Indonesia belum cukup membuktikan seberapa jauh efektivitas PBL di berbagai FK se-Indonesia. Bukti-bukti studi telah menggiring pada perbaikan PBL di berbagai lini termasuk tutor, desain PBL, asemen dan evaluasi program. Konsistensi pada penerapan hasil studi ini barangkali akan membuat kita berhenti memperdebatkan PBL pada tingkatan anekdotal; dan menjadikan PBL terus berkembang sesuai bukti ilmiah penerapannya di FK Indonesia.

Akhirnya, kembali pada prinsip pembelajaran metode SCL; PBL hanyalah salah satu pendekatan SCL. SansonFisher dan Lynagh ${ }^{29}$ mengusulkan agar kita mempertimbangkan variasi metode lain selain PBL. Kedua penulis menyoroti kurangnya diseminasi metode pembelajaran yang lain dibandingkan dengan PBL di fakultas kedokteran.

\section{DAFTAR PUSTAKA}

1. Bodner G. Constructivism: a theory of knowledge. J Chem Educ. 1986;63(10):873-8.

2. Phillips DC, Soltis JF. Perspectives on learning. New York: Teachers College Press, 2009.
3. Nurrenbern SC. Piaget's theory of intellectual development revisited. J Chem Educ. 2001;78(8): 1107.

4. Vygotski LS, Mind in society: the development of higher psychological processes. Cambridge: Harvard University Press, 1978.

5. Bodner G, Klobuchar M, Geelan D. The many forms of constructivism. J Chem Educ. 2001;78:1107.

6. Abraham MR. Inquiry and the learning cycle approach. In: Pienta NJ, Cooper MM, Greenbowe TJ, editors. Upper Saddle River, NJ: Pearson Prentice Hall, 2005: 41-52.

7. Gijselaers W. Bringing problem-based learning to higher education: theory and practice. San Francisco: Jossey-Bass, 1996.

8. Hays R. Balancing academic medicine. Med J Australia. 2007;186(3):110-1.

9. Vernon DTA, Blake RL. Does problem-based learning work? a meta-analysis of evaluative research. Acad Med.1993;68(7):550-63.

10. Albanese M, Mitchell S. Problem-based learning a review of literature on its learning outcomes and implementation issues. Acad Med. 1993;68(1):5281.

11. Rukmini E. Cost-effectiveness on PBL based on the experience in pilot PBL. In: PEPKI III, The $3^{\text {rd }}$ Indonesian Medical Education Meeting and Expo. Bali: AIPKI, 2006.

12. Rukmini E. Evaluation of pilot PBL implementation. Jurnal Pendidikan Kedokteran dan Profesi Kesehatan Indonesia. 2006;1(2).

13. Rukmini E, Ratnawati L. Evaluation on the problembased learning: a study of diverse range students' evaluations at the School of Medicine Atma Jaya Catholic University Indonesia. In: $1^{\text {st }}$ SEARAME International Conference and $5^{\text {th }}$ Indonesian Scientific Medical Education Expo and Meeting. Jakarta: AIPKI, 2010.

14. Dochy F, Segers M, Bossche PV, Gijbels D. Effects of problem-based learning: a meta-analysis. Learning and Instruction. 2003;13(5):533-68.

15. Clark CE. Problem-based learning: how do the outcomes compare with traditional teaching? Br J Gen Pract. 2006;56(530):722-3.

16. Mamade S, Schmidt HG, Geoffrey NR. Innovations in problem-based learning: what can we learn from recent studies? Adv Health Sci Educ. 2006;11:40322.

17. Hung W. The 9-step problem design process for problem-based learning: application of the $3 \mathrm{C} 3 \mathrm{R}$ model. Educational Research Review. 2009;4:11841. 
18. Dolmans DH, Schmidt HG. What do we know about cognitive and motivational effects of small group tutorials in problem-based learning? Adv Health Sci Educ. 2006;11:321-36.

19. Goodnough K. Enhancing pedagogical content knowledge through self-study: an exploration of problem-based learning. Teach High Educ. 2006;11(3):301-18.

20. Newman M. Fitness for purpose evaluation in problem based learning should consider the requirements for establishing descriptive causation. Adv Health Sci Educ. 2006;11:381-402.

21. Verkoeijen PPJL, Rikers RMJP, Te Winkel WWR, Van Den Hurk MM. Do student-deûned learning issues increase quality and quantity of individual study? Adv Health Sci Educ. 2006;11:337-47.

22. Te Winkel WWR, Rikers RMJP, Loyens SMM, Schmidt H. Inûuence of learning resources on study time and achievement scores in a problem-based curriculum. Adv Health Sci Educ. 2006;11:381-9.

23. Maudsley G. Making sense of trying not to teach: an interview study of tutors' ideas of problem-based learning. Acad Med. 2002;77(2):163-72.
24. Shields H, Guss D, Somers S, Kergoot B, Mandell B, Travassos W, et al. A faculty development program to train tutors to be discussion leaders rather than facilitators. Acad Med. 2007;82(5):486-92.

25. Gijbels D, Dochy F, Van DB, Segers M. Effects of problem-based learning: a meta-analysis from the angle of assessment. Rev Educ Res. 2005;75(1):27-61.

26. Usmani A, Sultan ST, Ali S, Fatima N, Babar S. Comparison of students and facilitators' perception of implementing problem based learning. Journal of Pakistan Medical Association. 2007;61(4):332-5.

27. Papinczak T. Are deep strategic learners better suited to PBL? A preliminary study. Adv Health Sci Educ. 2009; 14:337-53.

28. Reid WA, Duvall E, Evans P. Can we influence medical students' approaches to learning? Med Teach. 2005;27(5):401-7.

29. Sanson-Fisher RW, Lynagh MC. Problem-based learning: a dissemination success story? Med J Australia. 2005;183(5):258-60. 